\title{
Trade Liberalization and Wage Inequality in India: A Mandated Wage Equation Approach
}

\author{
Prachi Mishra \\ Research Department, IMF \\ Deb Kusum Das \\ Ramjas College, Delhi University
}

July 2012

\begin{abstract}
This paper uses an empirical approach based on the "mandated wage equations" to examine the relationship between trade liberalization and urban manufacturing wages in India. The main result in the paper is that trade reforms have been associated with a rise in the relative wages of medium-skilled workers (defined as having completed secondary schooling). We do not find any evidence for trade reforms to be associated with an increase or decrease in wage inequality between low and high-skilled workers. The results are consistent with the predictions of the Stolper-Samuelson theorem.
\end{abstract}

JEL Classification Numbers: F16, J31.

Keywords: Trade liberalization, wages, India 


\section{Introduction}

There is a growing consensus in the literature that trade liberalization by developing countries has raised aggregate incomes. However, the internal distributional effects of trade reforms and the effect on labor markets are still debated. ${ }^{1}$ This paper presents new evidence from India on the impact of trade liberalization on wage inequality.

In 1991, after decades of pursuing an import-substitution industrialization strategy, India initiated a drastic liberalization of its external sector. The average tariff in manufacturing declined from 117 percent in 1990-91 to 39 percent in 1999-2000. The reduction in tariffs was more drastic in India than in the trade liberalization episodes in Latin American countries like Mexico, Colombia, and Brazil (Figure 1). In addition to tariffs, India has also reduced non-tariff barriers (NTBs) since 1991. The average import coverage ratio (the share of imports subject to non-tariff barriers) declined from 82 percent in 1990-91 to 17 percent in 1999-2000.

In this paper, we revisit the link between trade liberalization and wages in India. Specifically, the question we address is: has trade liberalization been associated with increased or decreased wage inequality across different skill categories? The focus of this paper will be on urban manufacturing wages.

The empirical approach in this paper uses "mandated wage equations" (Baldwin and Cain 2000, Leamer 1998). The mandated wage equations are based on the standard

\footnotetext{
${ }^{1}$ See Goldberg and Pavcnik (2007) for a survey.
} 
general equilibrium trade model and predict the change in factor costs that are needed to keep the zero-profit conditions operative in the face of changing product prices.

The main finding in this paper is that trade liberalization has been associated with a rise in relative wages of medium-skilled workers (defined as having attained secondary schooling) in the manufacturing sector. We show that the predicted wages of medium-skilled rise relative to both high (higher secondary or more education) and low-skilled (primary education) workers. In other words, medium-skilled workers benefit both relative to low and high-skilled workers. The rise in the relative wages of medium-skilled vis-à-vis high-skilled workers due to trade liberalization in India is consistent with the standard intuition from the Stolper-Samuelson theorem, whereby trade liberalization benefits a country's relatively abundant factor.

The rise in the wages of medium-skilled relative to low-skilled workers can also be rationalized within the Stolper Samuelson framework. This is because the largest tariff reductions (and hence the largest reduction in prices) were in sectors employing a higher fraction of low-skilled workers and those with a lower fraction of mediumskilled workers, leading to a rise in the relative price of medium-skill-intensive goods and an increase in return to medium-skilled labor.

There exists a vast empirical literature that considers the relationship between trade reforms and income distribution in India. There are two ways in which this paper moves beyond the existing literature. First, it applies a new methodology to study the 
relationship between trade reforms and wage inequality in India. Most existing papers focus on variation across geographical regions (e.g. Hasan, Mitra and Ural, 2007 and Topalova, 2010), or industries (e.g. Kumar and Mishra, 2008). While these papers can establish differential effects on inequality across regions/industries with different exposures to trade, they cannot ascertain the effect of trade reforms on overall income distribution. The mandated wage equation approach used in this paper makes a contribution towards filling this gap in the literature.

The second contribution of this paper is to add to the debate on trade reforms and inequality in India by focusing on the variation in skill categories. Rather than assigning workers to either "unskilled" or "skilled" groups (typically defined in the literature in terms of production and non-production workers) ${ }^{2}$, we show that broadening the categories of skills may be meaningful. The findings in this paper suggest beneficial effects of trade reforms for medium-skilled workers in manufacturing. Without disaggregating the skill categories, we could have the erroneous effect of skilled workers benefiting vis-à-vis the unskilled workers. Such a result would have very different implications for effects of liberalization on inequality than what is being suggested by the findings here.

This rest of the paper is organized as follows. Section II presents the standard general equilibrium relationship between changes in product prices and changes in factor

\footnotetext{
${ }^{2}$ See for example, Robertson (2004).
} 
prices, Section III lays out the empirical strategy, Section IV describes the data and Section V discusses the results. Section VI concludes.

\section{Theory}

The neoclassical Heckscher-Ohlin framework suggests that changes in trade policy affect wages through changes in relative prices of goods (Stolper Samuelson theorem). Representing the unit costs as a function of factor prices as $\mathrm{c}(\boldsymbol{w})$, output prices as $\boldsymbol{p}$, output volume as $\boldsymbol{y}$, factor endowments with vector $\boldsymbol{v}$, we can express the assumptions of perfect competition and full employment as

$$
\begin{aligned}
& c(\mathbf{w})=\mathbf{p} \\
& \sum_{i} c_{w}(\mathbf{w}) y_{i}=\mathbf{v}
\end{aligned}
$$

Totally differentiating (1) and solving to express the change in factor prices as a function of product prices we have

$$
\hat{p}=A \hat{w}
$$

where $A$ is a matrix of factor cost shares and the circumflexes $(\wedge)$ indicate percentage changes. For the standard two-goods, two-factors trade model, equation (2) implies that an increase in the relative price of one of the goods increases the real price of the factor used intensively in producing that good, and lowers the real price of the other factor. This is the standard Stolper-Samuelson theorem. 
Ethier (1984) and Deardorff (1994) have demonstrated that with more than two goods and two factors the Stolper-Samuelson relationship holds in the sense that, on average, factors used intensively in the rising price sectors will themselves rise in price, while the factors used intensively in the falling price sectors will fall in price. For any vector of goods price changes, the accompanying vector of factor price changes will be positively correlated with the factor intensity weighted averages of goods price changes (Deardorff, 1994).

Leamer (1998) uses the term "mandated wage equations" to predict the change in wages that would be consistent with Stolper-Samuelson effects. The basis for this approach is the idea that cross-industry product-price changes should be proportional to common across-industries factor price changes where the factor of proportion is the industry's factor shares. The idea is that since the factor matrix in (2) is not invertible, one cannot estimate (2) directly. A wage vector is estimated by regressing the vector of price changes across time on the factor share matrix. The estimated vector is then compared to actual wage changes.

Baldwin and Cain (2000) interpret (2) with the following regression equation:

$\hat{p}_{j}=\alpha+\sum_{i} \hat{w_{i}} \theta_{i j}+e_{j}$ 
in which $i$ is the factor index and $\theta$ is the share of factor $i$ employed by industry $j$. The variables $p_{j}$ and $w_{i}$ represent the output price in industry $j$ and the economy wide return to factor $i$ respectively. Equation (3) can be used to estimate proportional changes in factor prices in a given period, assuming unchanged technological conditions.

In this approach the factor shares are the independent variables and prices are the dependent variables. The parameters to be estimated are the changes in the wages (over the sample period) that are assumed to be equal across all industries because factors are assumed to be perfectly mobile across industries. If the predicted changes match the actual changes, then Stolper Samuelson effects are said to have a large role in determining wages.

The existing literature has identified several estimation issues with the mandated wage equation (e.g. Baldwin and Cain, 2000, Robertson, 2004, Feenstra and Hanson, 1999). First, there are concerns relating to exogeneity of price changes. If technology is changing, and technology affects prices, then the estimates may be biased. As discussed below we will be using tariffs (rather than prices) to estimate Equation (3), which may lessen such concerns. It may be argued that trade reforms in India were exogenous and came as a surprise to the policy makers. In response to a severe balance of payments crisis in 1991, India approached the International Monetary Fund for assistance. The IMF support was conditional on structural reforms including trade liberalization, which India launched. The government's objectives when reducing trade barriers were thus given by IMF conditionalities. 
The second issue relates accounting for intermediate inputs in measuring prices, given the large and growing share of intermediate goods trade. Davis and Mishra (2007) argue how liberalization in final and intermediate goods can have opposing effects for wage inequality. They show that trade liberalization can benefit high-skilled labor in developing countries if liberalization takes place primarily in intermediate goods. In order to address this concern, we use effective rates of protection for the empirical analysis in this paper. ${ }^{3}$

Third, Feenstra and Hanson (1999), Robertson (2004) use a two-step procedure to estimate the contribution of tariff changes on wages. In the first step, price changes are regressed on tariff changes. The predicted price changes are then regressed in the second step on factor shares to get the predicted wage changes. Since we do not have data on prices at the 3-digit industry level, we will use a single-equation estimation of the mandated wage equation as described below.

\section{Empirical Strategy:}

We estimate the following regression equation

$$
\hat{t_{j}}=\alpha+\sum_{i} \hat{w_{i}} \theta_{i j}+e_{j}
$$

\footnotetext{
${ }^{3}$ For robustness, we will also repeat the analysis with nominal rather than effective tariff rates.
} 
where $\hat{t}_{j}$ is the proportional change in the tariff rate. The dependent variable is the change in the tariff rates. The explanatory variables are the initial period factor shares of low, medium and high-skilled workers employed in industry $j$. By using tariff rates, one can estimate the changes in factor costs attributable to changes in trade policy.

Relative factor prices can change when relative product prices change due to reasons other than changes in tariffs e.g. technological change. Unless it is uniform across industries, technological progress changes the relative productivity of the factors without any change in the relative product prices (direct effects of technical change). The resulting relative output effects result in changes in the relative product prices that result in further changes in relative factor prices via the Stolper Samuelson relationship (indirect effect of technical change).

The changes in relative factor prices due to reasons other than tariffs are not captured in Equation (4). Our aim is to isolate the effect of changes in factor prices consistent with tariff changes. Baldwin and Cain (2000) use an empirical strategy similar to (4) isolate the effect of international trade on factor prices. They, however, use changes in the trade ratio ((exports - imports) /domestic consumption) instead of changes in tariffs.

Note that this paper is not trying to estimate the effect of trade reforms on productivity in India. Changes in total factor productivity (TFP) would be a concern if 
they constitute a source of omitted variable bias in Equation (4) i.e. two conditions are satisfied: (i) changes in TFP are correlated with the unobserved component of tariff changes and (ii) TFP changes are also correlated with the explanatory variable (4) i.e. the initial period factor shares. Such endogeneity concerns are likely to be less severe due to two reasons. First, the dependent variable in our regressions is not changes in prices, rather it is changes in tariffs, which are more likely to be exogenous and not correlated with TFP changes. Second, and importantly, the explanatory variable is the initial period factor share, therefore, is less likely to be correlated with the unobserved component of contemporaneous tariff changes.

\section{Data}

We use repeated cross-sections drawn from the Employment-Unemployment Schedule of the National Sample Survey Organization (NSSO) administered by the Government of India. NSSO provides information on weekly earnings, worker characteristics e.g., age, education, gender, marital status, occupation, industry of employment at three-digit National Industrial Classification (NIC-1987) and state of residence. We use information from three survey rounds conducted in 1987-88, 199394 and 1999-00 and focus on the manufacturing sector, since the tariff reductions have been the largest in manufacturing, whereas agriculture has been relatively closed to trade liberalization. Further, we restrict attention to workers in urban areas as the manufacturing sector is mostly concentrated in urban India. Finally, we include in our sample only those workers between the ages of 15 and 65, who are a part of the labor force and report positive weekly earnings. 
Wages are measured by weekly earnings. ${ }^{4}$ The individuals are classified into three groups by the years of completed schooling: (i) low-skilled workers: those with primary education or less (at most 5 years of schooling) (ii) medium-skilled workers: those with middle or secondary education (6-11 years of schooling) (iii) high-skilled workers with higher secondary or more education (at least 12 years of schooling). ${ }^{5}$

As shown in Figure 2, India is relatively abundant in low and medium-skilled labor. For example, in 1999-00, based on the NSS, $40 \%$ of the workers were low-skilled, $38 \%$ were medium-skilled and $22 \%$ were high-skilled. The proportion of high-skilled in the workforce has almost doubled between 1987-88 and 1999-00. The proportion of medium-skilled, in contrast has remained relatively stable over time.

Table 1 shows some descriptive statistics on wages in India. The average wages, and wages for different skill categories have increased in India between 1987-88 and 1999-00. The relative wages of medium-skilled workers have increased by $15 \%$ between 1983-84 and 1999-00, whereas those for high-skilled have risen by almost $30 \%$ during the same time period.

The international trade data on India that we use in this paper is from Das (2003). This database covers 72 three-digit manufacturing industries, classified according to the National Industrial Classification 1987 (NIC-1987). In addition to tariff rates, the

\footnotetext{
${ }^{4}$ Note that data on hourly wages is not available in the NSSO.

${ }^{5}$ Skill categories are defined by the variable "pergened" in the NSS, which denotes the years of schooling. Low-skilled are defined by pergened $<=6$; medium-skilled by pergened $=7,8$ and high-skilled by pergened $>=9$. The definition of skill categories remain unchanged during the three rounds we use in the paper.
} 
dataset also includes effective rates of protection, and import coverage ratios. The details of the data are described in the appendix.

Figure 1 shows the average tariff for the 72 manufacturing industries in the 1980s and the 1990s. The average tariff in manufacturing increased from 86 percent in 1980-81 to 117 percent in $1990-91$, and then declined to 39 percent in 1999-2000. In comparison, the trade reforms in Brazil reduced the average tariff level in manufacturing from about 60 percent in 1987 to 15 percent in 1998; in Colombia, from 50 percent to 13 percent between 1984 and 1998. Between 1980 and 1990, the average tariffs in Mexico decreased from 23 percent to 13 percent. Thus, the percentage point reduction in average tariffs between 1990-91 and 1999-2000 was more drastic in India than in the Latin American countries

Figure 3 shows the average effective rates of protection over our sample period. The average effective tariff rate has decreased by two-thirds between 1987-88 and 19992000. Overall, there are 55 3-digit manufacturing industries for which we have information on both wages and effective tariff rates. ${ }^{6}$

\section{Results}

We estimate equation (4) separately for each of the three time periods: (i) 1987-88 to 1993-94 and (ii) $1993-94$ to $1999-2000$, and (iii) $1987-88$ to $1999-2000$. In addition, we also estimate the equation for the pooled sample combining the three sample

\footnotetext{
${ }^{6}$ We have information on both tariffs and wages for 65 industries during 1987-88 to 1993-94, but to keep the sample balanced, we restrict the empirical analysis to 55 industries.
} 
periods. The advantage of the pooled specification is that it allows us to introduce year fixed effects to control for any technological change common across all industries. The explanatory variables are the initial period average factor shares for the three categories of workers. For example, the factor share of low-skilled workers in a given industry is measured by the share of low-skilled workers employed in that industry. We use factor shares in 1987-88 for the regressions covering the periods 1987-88 to 1993-94 and 1987-88 to 1999-2000; and the 1993-94 factor share for the 1993-94 to 1999-2000 regressions. Following Baldwin and Cain (2000), the regressions are weighted by industry employment. ${ }^{7}$

The results from estimating (4) are shown in Table 2. The estimated coefficient on the share of both low- and high-skilled workers, which can be interpreted as the predicted change in their wages, is negative for all the time periods. The predicted change in the wages of low-skilled is statistically significant for $1987-88$ to $1999-2000$, whereas that for the high-skilled is significant in all the periods except for 1987-88 to 19931994. In contrast, the estimated coefficient on factor share of medium-skilled workers is positive in all the periods, and statistically significant for $1987-88$ to $1999-2000 .^{8}$

The difference in the share coefficients of skilled and unskilled workers can be interpreted to be a measure of predicted wage inequality. The difference between the predicted wages of medium and high-skilled workers is positive for all time periods; the difference between medium and low-skilled workers is positive as well.

\footnotetext{
${ }^{7}$ Unweighted regressions produce similar coefficients but with higher standard errors.

${ }^{8}$ When we introduce year fixed effects, the results for the pooled sample are similar to those reported in Table 1.
} 
Therefore, medium-skilled workers appear to gain relative to both high and lowskilled workers. The difference is significant (at least at the $15 \%$ level) in the periods 1993-94 to $1999-2000$ and for $1987-88$ to $1999-2000$. The lack of significance for the period 1987-88 to 1993-94 may be consistent with the idea that the effect of tariffs and hence goods prices on factor prices may take some time to emerge.

The estimated coefficients suggest that the predicted wages of medium-skilled workers increased roughly by 37 percent due to changes in tariffs over the period $1987-88$ to $1999-00$. The mandated wage equations, thus, predict a reduction in wage inequality between medium and high-skilled workers owing to trade liberalization in India.

Interestingly, we do not find evidence of any change in wage inequality between highest and lowest skilled workers owing to trade reforms. The difference in the predicted wages of high and low-skilled workers is not statistically significant in any of the time periods.

The actual proportionate change in wages and the comparison between the predicted and actual changes are also shown in Table 3 . The actual changes are positive for low, medium and high-skilled workers in all the sample periods. The predicted changes in the wages of medium-skilled workers are statistically not different from the actual changes for all the periods (at 5 percent significance or less). Therefore Equation (4) fits well for predicting the actual wages of medium-skilled workers. 
The predicted change in wages of low-skilled workers is statistically different from actual changes in the period from 1987-88 to 1999-2000, the predicted and actual are not different for the other time periods. For high-skilled workers, the predicted changes are statistically different from the actual changes for all the sample periods (except for 1987-88 to 1993-94). These findings suggest that other factors like technology changes may also be important in determining the actual wage changes of high-skilled workers.

The predicted rise in the relative wages of medium-skilled workers relative to highskilled due to trade liberalization in India is consistent with the intuition from the Stolper-Samuelson theorem, which in simple terms states that trade liberalization will benefit a country's relative abundant factor.

The rise in the relative wages of medium vis-à-vis low-skilled workers may be surprising. However, the predicted rise in the skill-premium for medium-skilled workers vis-à-vis low-skilled can also be rationalized within the more general framework of the Stolper-Samuelson theorem. When we compare the magnitude of tariff reductions across sectors, the biggest reductions occurred in sectors employing a higher fraction of low-skilled workers, but a lower fraction of medium-skilled workers (Figures $4 \mathrm{a}$ and $4 \mathrm{~b}$ ). Therefore, the Stolper-Samuelson theorem would predict a rise in the relative price of medium skill-intensive goods and therefore a rise in the return to medium-skilled labor. Hanson and Harrison (1999) and Attanasio et al 
(2003) also find that tariff reductions were higher in sectors with bigger share of unskilled workers for Mexico and Colombia respectively. However, our paper suggests that combining low and medium skill workers may miss some of the interesting variation within skill categories.

We conduct two additional checks for the main results. First we use nominal rather than effective rates of protection. The evolution of nominal tariff rates in manufacturing is shown in Figure 5. The results shown in Table 4 are qualitatively similar (except in the period 1987-88 to 1993-94). The predicted rise the in wages of medium-skilled workers over the period $1987-88$ to $1999-00$ is however, muted, relative to the baseline in Table 2. This is not surprising given that liberalization in intermediate goods could dampen some of the benefits to medium-skill workers.

Second, in addition to tariffs, India also reduced its non-tariff barriers since 1991 (Figure 6). The measure of non-tariff barriers we use is the "import coverage ratio" which is defined as the share of imports subject to non-tariff barriers. Our findings (not shown) are weaker when we use the coverage ratios instead of tariffs in estimating Equation (4). However, we still find the predicted wages of mediumskilled workers to increase relative to both high and low-skilled workers.

The results in this paper are comparable to Robertson (2004)'s study of Mexico who finds that the predicted wage inequality increased in the period following Mexico joining the GATT in 1985. However, the mandated wage equations predict a fall in 
wage inequality in Mexico between1996-1999 in the post NAFTA period. Robertson (2004) argues that Mexico liberalized trade with a less skill abundant world when it joined the GATT in 1985. Following the entrance to the GATT, the relative price of the skill-intensive goods rose, consistent with the predictions of the StolperSamuelson theorem, the relative wage of skilled workers rose. On the other hand, after NAFTA, Mexico liberalized on skill intensive goods it traded with US and Canada, and the relative price of skill intensive goods fell, and are consistent with the predictions of the Stolper-Samuelson, the relative wage of skilled workers fell.

\section{Conclusion}

This paper uses an empirical approach based on the "mandated wage equations" to examine the relationship between trade liberalization and wages in India. The mandated wage equation predicts a rise in relative wages of medium-skilled workers due to trade liberalization. We do not find any evidence for wage inequality between high and low-skilled workers to change following the trade reforms. The rise in the relative wages of medium-skilled workers is consistent with the predictions of the Stolper-Samuelson theorem. 


\section{References}

Baldwin, R.E., Cain, G.G., 2000. Shifts in Relative U.S. Wages: The Role of Trade, Technology, and Factor Endowments. Review of Economics and Statistics. 82(4), November. 580--95.

Das, D.K., 2003. Quantifying Trade Barriers: Has Protection Declined Substantially in Indian Manufacturing? ICRIER (Indian Council for Research on International Economic Relations) Working Paper \# 105.

Stolper-Samuelson is Dead and Other Crimes of Both Theory and Data (with Donald Davis, Columbia University), in Ann Harrison eds. Globalization and Poverty: University of Chicago Press and the National Bureau of Economic Research, March, 2007.

Deardorff, A.V., 1994. Overview of the Stolper-Samuelson Theorem in: Alan V.

Deardorff and Robert M. Stern (eds) The Stolper Samuelson Theorem: A Golden Jubilee. Ann Arbor: University of Michigan Press. 7--34.

Ethier, W.J., 1984. Higher Dimensional Issues in Trade Theory in: R.W. Jones and P.B. Kennen (Eds.), Handbook of International Economics, volume 1. Amsterdam: North Holland. 131--184.

Feenstra, R.C., Hanson, G., 1999. The Impact of Outsourcing and High Technology Capital on Wages: Estimates for the United States, 1979-1990. Quarterly Journal of Economics. 114(3), August. 907--40.

Goldberg, Pinelopi and Nina Pavcnik, 2007, Distributional Effects of Globalization in Developing Countries, Journal of Economic Literature, March, 45(1), pp 39-82. 
Hasan, R., Devashish Mitra and Beyza P. Ural, 2007, Trade Liberalization, Labor Market Institutions, and Poverty Reduction: Evidence from Indian States, BrookingsNCAER India Policy Forum, 2006-07.

Leamer, E.E., 1998. In Search of Stolper-Samuelson Linkages between Trade and Lower Wages in: Collins, S. (ed.) Imports, Exports and the American Worker Brookings Institute Press. 141--202.

Robertson, R., 2004. Relative Prices and Wage Inequality: Evidence From Mexico. Journal of International Economics, 2004, No. 64, pp. 387-409.

Topalova, Petia, 2010. "Factor Immobility and Regional Impacts of Trade Liberalization: Evidence on Poverty from India," American Economic Journal: Applied Economics, American Economic Association, vol. 2(4), pages 1-41, October.

Dutta, Puja Vasudeva, 2007. "Trade Protection and Inter-Industry Wages in India," Industrial and Labor Relations Review, ILR Review, Cornell University, ILR School, vol. 60(2), pages 268-286, January. 
Table 1: Average Weekly Earnings in India

\begin{tabular}{ccccccc}
\hline & $\begin{array}{c}\text { All } \\
\text { workers }\end{array}$ & Low-skilled & $\begin{array}{c}\text { Medium- } \\
\text { skilled }\end{array}$ & High-skilled & Medium/Low High/Low \\
\hline $1987-88$ & 264 & 209 & 277 & 512 & 1.3 & 2.5 \\
$1993-94$ & 407 & 241 & 399 & 791 & 1.7 & 3.3 \\
$1999-00$ & 790 & 469 & 709 & 1507 & 1.5 & 3.2 \\
\hline
\end{tabular}

The average weekly earnings are in rupees. Low-skilled workers are defined as having attained primary schooling, medium-skilled as having secondary and high-skilled workers are defined as higher secondary or more schooling. The reported earnings are for workers in the urban areas who work in the manufacturing sector, who are between the ages of 15 and 65, who are a part of the labor force and report positive weekly earnings. 
Table 2: Mandated Wage Equation Results:

$$
\hat{t_{j}}=\alpha+\sum_{i} \hat{w_{i}} \theta_{i j}+e_{j}
$$

Dependent variable: Difference in effective tariff rates as a proportion of the initial tariff rate in industry $j$

\begin{tabular}{|c|c|c|c|c|}
\hline & $\begin{array}{c}\text { Pooled } \\
\text { sample } \\
\text { (all rounds) }\end{array}$ & $\begin{array}{c}1987-88 \\
\text { to } \\
1993-94\end{array}$ & $\begin{array}{l}1993-94 \\
\text { to } \\
1999-00\end{array}$ & $\begin{array}{c}1987-88 \\
\text { to } \\
1999-00\end{array}$ \\
\hline $\begin{array}{l}\text { Share of low-skilled workers } \\
\text { employed in industry } j\end{array}$ & $\begin{array}{l}-5.21 \\
(5.34)\end{array}$ & $\begin{array}{l}-8.37 \\
(11.51)\end{array}$ & $\begin{array}{l}-12.04 \\
(7.77)\end{array}$ & $\begin{array}{l}-27.50^{* *} \\
(12.78)\end{array}$ \\
\hline $\begin{array}{l}\text { Share of medium-skilled } \\
\text { workers employed in } \\
\text { industry } j\end{array}$ & $\begin{array}{c}4.54 \\
(7.28)\end{array}$ & $\begin{array}{c}3.79 \\
(13.90)\end{array}$ & $\begin{array}{c}19.54 \\
(12.20)\end{array}$ & $\begin{array}{l}36.64^{*} \\
(20.05)\end{array}$ \\
\hline $\begin{array}{l}\text { Share of high-skilled } \\
\text { workers employed in } \\
\text { industry } j\end{array}$ & $\begin{array}{l}-5.32^{* * *} \\
(2.74)\end{array}$ & $\begin{array}{l}-4.00 \\
(5.13)\end{array}$ & $\begin{array}{l}-9.24^{* * *} \\
(3.33)\end{array}$ & $\begin{array}{l}-18.50^{* * *} \\
(5.47)\end{array}$ \\
\hline $\begin{array}{l}\text { Share of medium-skilled - } \\
\text { low-skilled different from } \\
\text { zero ( } p \text { value) }\end{array}$ & 0.43 & 0.63 & 0.12 & 0.05 \\
\hline $\begin{array}{l}\text { Share of medium-skilled - } \\
\text { high-skilled different from } \\
\text { zero ( } p \text { value) }\end{array}$ & 0.32 & 0.68 & 0.06 & 0.03 \\
\hline $\begin{array}{l}\text { Share of high-skilled - low- } \\
\text { skilled different from zero } \\
\text { ( } p \text { value })\end{array}$ & 0.98 & 0.58 & 0.64 & 0.36 \\
\hline R-squared & 0.13 & 0.14 & 0.15 & 0.26 \\
\hline Observations & 110 & 55 & 55 & 55 \\
\hline
\end{tabular}


Table 3: Mandated Wage Equations - Comparing Predicted and Actual Changes in Wages

\begin{tabular}{|c|c|c|c|c|c|}
\hline & & $\begin{array}{l}\text { Pooled } \\
\text { sample } \\
\text { (all } \\
\text { rounds) }\end{array}$ & $\begin{array}{c}1987-88 \\
\text { to } \\
1993-94\end{array}$ & $\begin{array}{c}1993-94 \\
\text { to } \\
1999-00\end{array}$ & $\begin{array}{c}1987-88 \\
\text { to } \\
1999-00\end{array}$ \\
\hline $\begin{array}{l}\text { Low-skilled } \\
\text { workers }\end{array}$ & $\begin{array}{l}\text { Actual } \\
\text { proportionate } \\
\text { change in } \\
\text { wages }\end{array}$ & 0.41 & 0.15 & 0.66 & 0.81 \\
\hline $\begin{array}{l}\text { Predicted and } \\
\text { actual changes } \\
\text { are similar }\end{array}$ & $p$-value & 0.29 & 0.46 & 0.11 & 0.03 \\
\hline $\begin{array}{l}\text { Medium-skilled } \\
\text { workers }\end{array}$ & $\begin{array}{l}\text { Actual } \\
\text { proportionate } \\
\text { change in } \\
\text { wages }\end{array}$ & 0.47 & 0.36 & 0.57 & 0.94 \\
\hline $\begin{array}{l}\text { Predicted and } \\
\text { actual changes } \\
\text { are similar }\end{array}$ & $p$-value & 0.58 & 0.81 & 0.13 & 0.08 \\
\hline $\begin{array}{l}\text { High-skilled } \\
\text { workers }\end{array}$ & $\begin{array}{l}\text { Actual } \\
\text { proportionate } \\
\text { change in } \\
\text { wages }\end{array}$ & 0.54 & 0.43 & 0.64 & 1.1 \\
\hline $\begin{array}{l}\text { Predicted and } \\
\text { actual changes } \\
\text { are similar }\end{array}$ & p-value & 0.04 & 0.39 & 0.00 & 0.00 \\
\hline
\end{tabular}

Low-skilled workers are defined as having attained primary schooling, medium-skilled as having secondary and high-skilled workers are defined as higher secondary or more schooling. 
Table 4: Mandated Wage Equation Results: Nominal Tariff Rates

$$
\hat{t}_{j}=\alpha+\sum_{i} \hat{w}_{i} \theta_{i j}+e_{j}
$$

Dependent variable: Difference in nominal tariff rates as a proportion of the initial tariff rate in industry $j$

\begin{tabular}{|c|c|c|c|c|}
\hline & $\begin{array}{c}\text { Pooled } \\
\text { sample } \\
\text { (all rounds) }\end{array}$ & $\begin{array}{l}1987-88 \\
\text { to } \\
1993-94\end{array}$ & $\begin{array}{c}1993-94 \\
\text { to } \\
1999-00\end{array}$ & $\begin{array}{c}1987-88 \\
\text { to } \\
1999-00\end{array}$ \\
\hline $\begin{array}{l}\text { Share of low-skilled workers } \\
\text { employed in industry } j\end{array}$ & $\begin{array}{l}-0.85 \\
(2.86)\end{array}$ & $\begin{array}{l}10.36^{* *} \\
(4.28)\end{array}$ & $\begin{array}{l}-5.17 \\
(5.23)\end{array}$ & $\begin{array}{c}0.03 \\
(4.55)\end{array}$ \\
\hline $\begin{array}{l}\text { Share of medium-skilled } \\
\text { workers employed in } \\
\text { industry } j\end{array}$ & $\begin{array}{c}1.45 \\
(3.91)\end{array}$ & $\begin{array}{l}-15.65^{\star * *} \\
(5.17)\end{array}$ & $\begin{array}{l}11.06 \\
(8.20)\end{array}$ & $\begin{array}{l}14.21^{*} \\
(7.14)\end{array}$ \\
\hline $\begin{array}{l}\text { Share of high-skilled } \\
\text { workers employed in } \\
\text { industry } j\end{array}$ & $\begin{array}{l}0.34 \\
(1.47)\end{array}$ & $\begin{array}{l}6.94^{* * *} \\
(1.91)\end{array}$ & $\begin{array}{l}-3.78^{*} \\
(2.24)\end{array}$ & $\begin{array}{l}-3.10 \\
(1.95)\end{array}$ \\
\hline $\begin{array}{l}\text { Share of medium-skilled - } \\
\text { low-skilled different from } \\
\text { zero ( } p \text { value) }\end{array}$ & 0.73 & 0.01 & 0.23 & 0.03 \\
\hline $\begin{array}{l}\text { Share of medium-skilled - } \\
\text { high-skilled different from } \\
\text { zero ( } p \text { value) }\end{array}$ & 0.83 & 0.00 & 0.15 & 0.05 \\
\hline $\begin{array}{l}\text { Share of high-skilled - low- } \\
\text { skilled different from zero } \\
\text { ( } p \text { value })\end{array}$ & 0.55 & 0.24 & 0.73 & 0.03 \\
\hline R-squared & 0.02 & 0.23 & 0.06 & 0.11 \\
\hline Observations & 110 & 55 & 55 & 55 \\
\hline
\end{tabular}


Figure 1. Average Tariff Rates: India and Latin America $(1980-81$ to $1999-2000)$

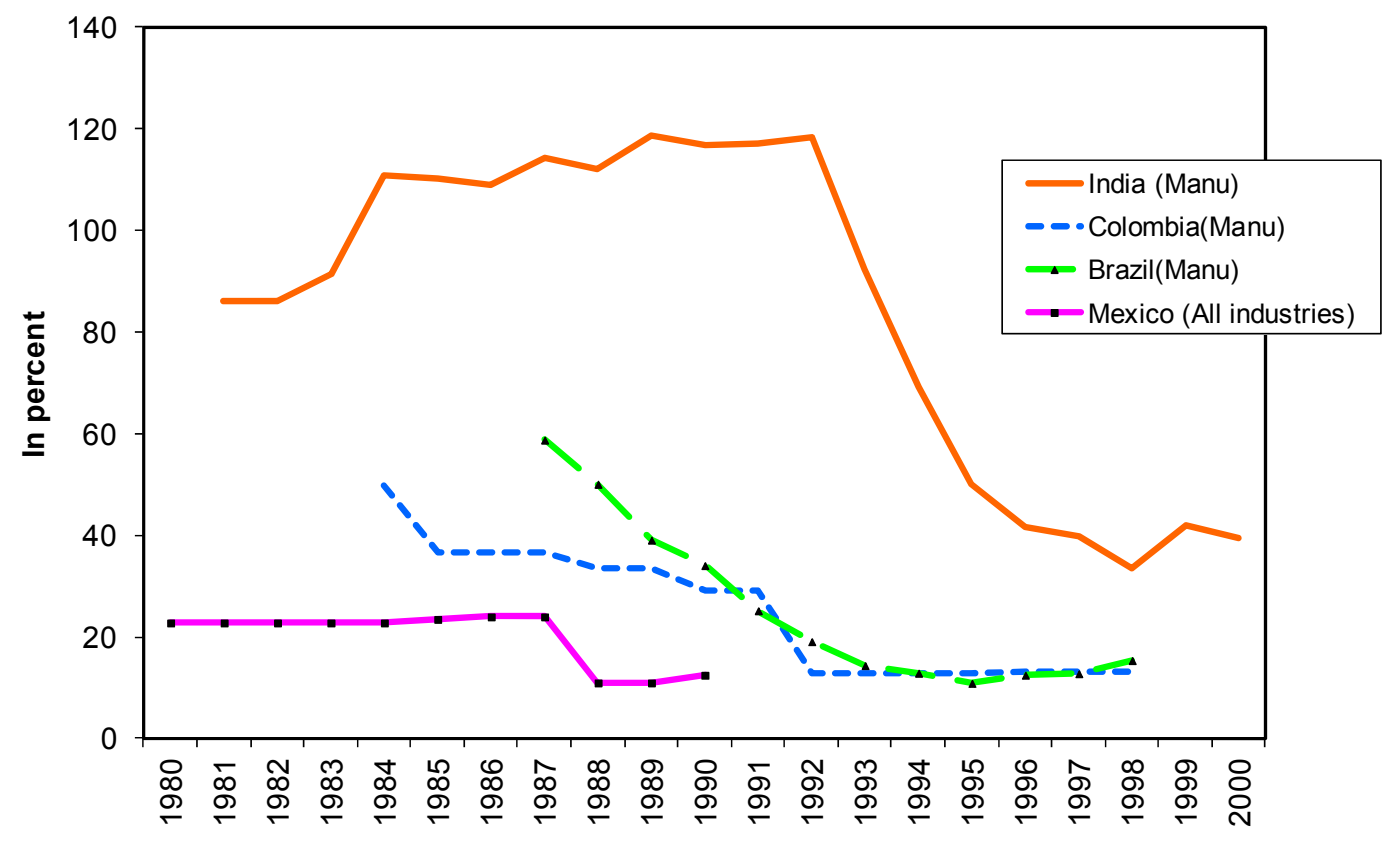



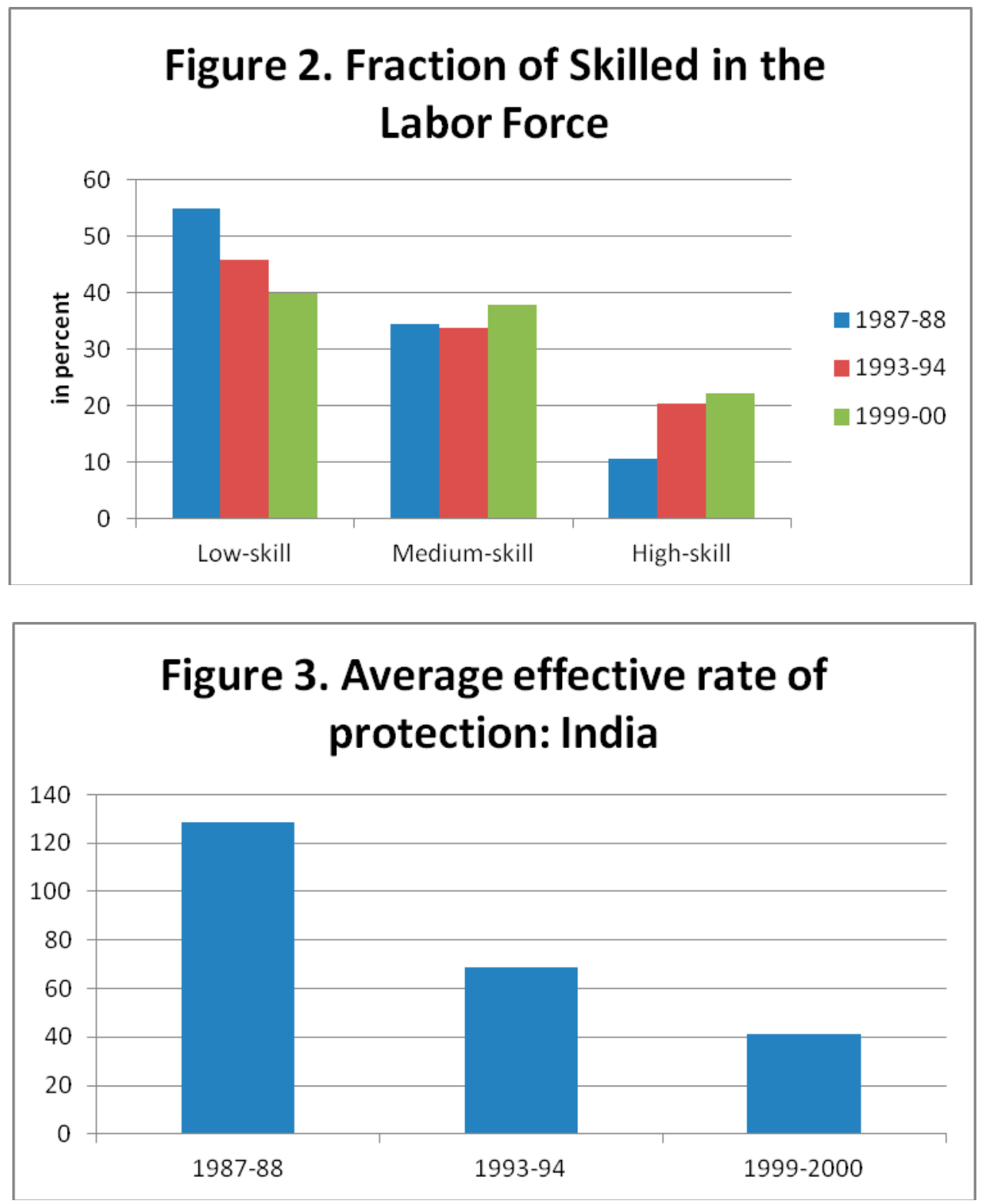

Note. The average effective rates of protection are for 72 three-digit manufacturing industries classified according to the National Industrial Classification 1987 (NIC-1987). 
Figure 4a. Tariff Reduction b/w 1993-94 and 1999-00 and Share of Low-skilled workers

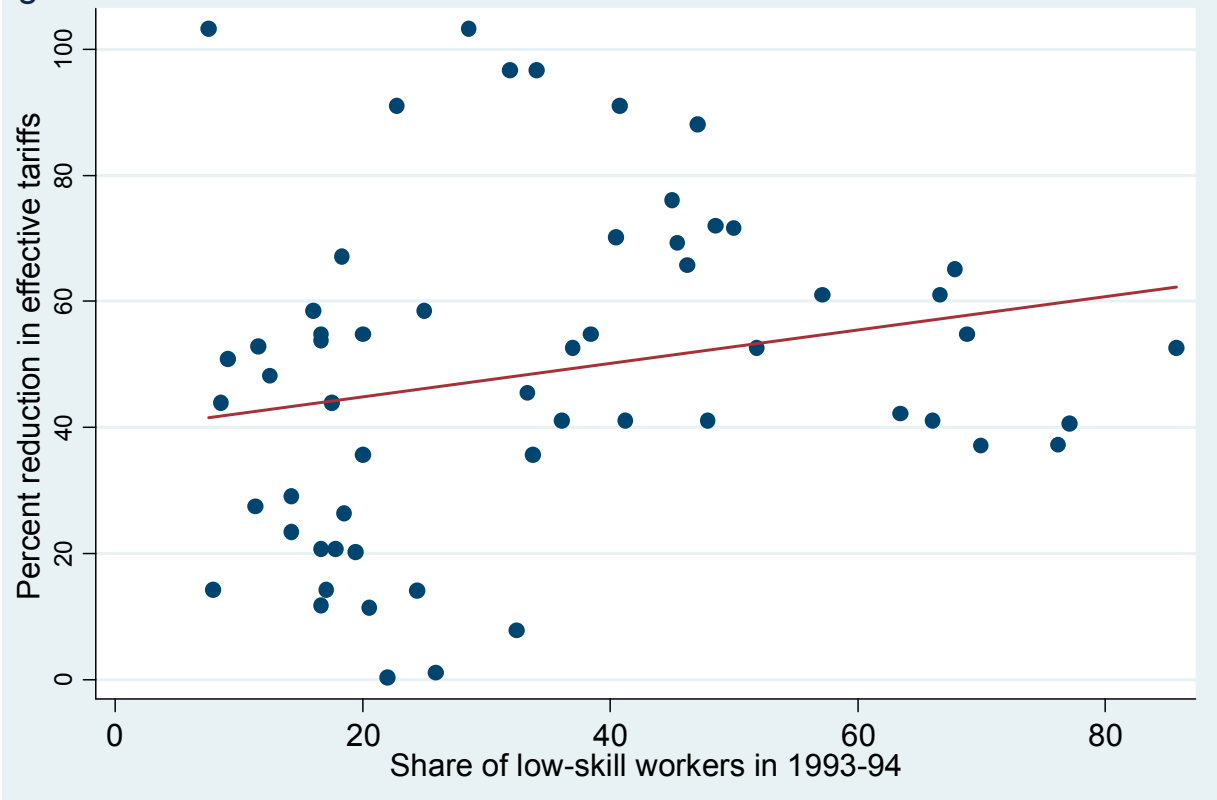

Figure 4b. Tariff Reduction b/w 1993-94 and 1999-00 and Share of Medium-skilled workers

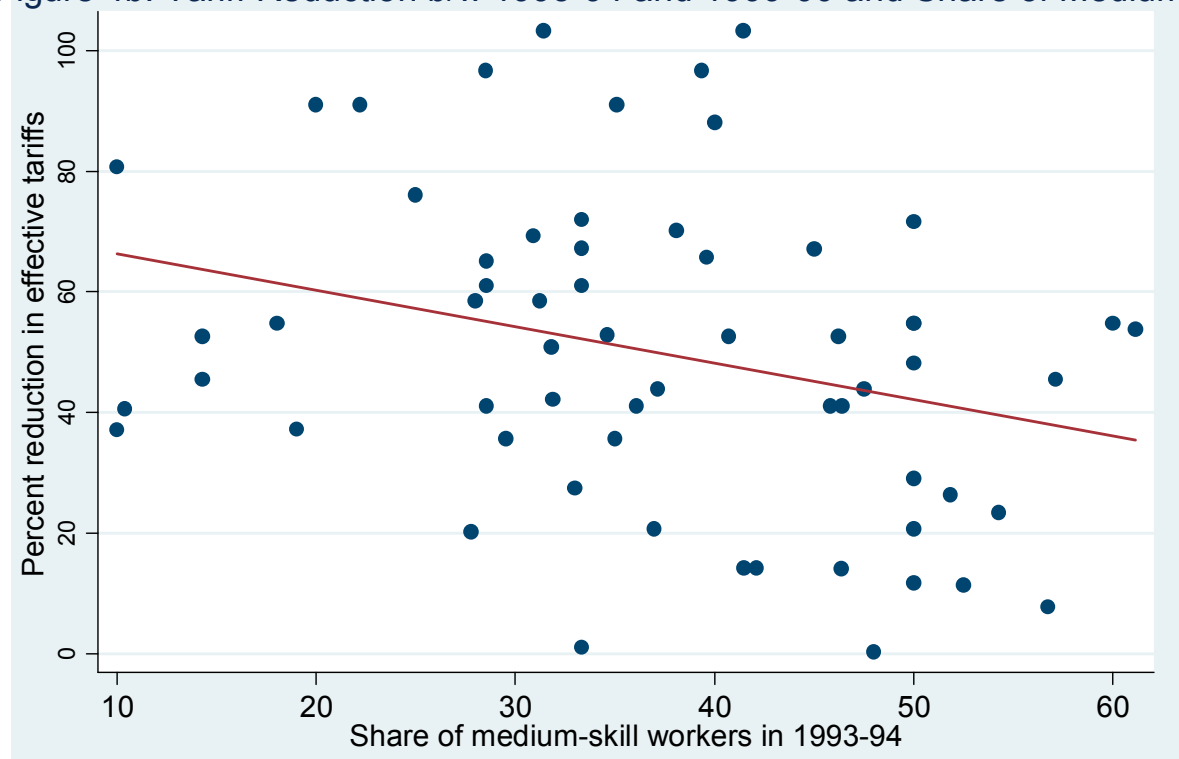



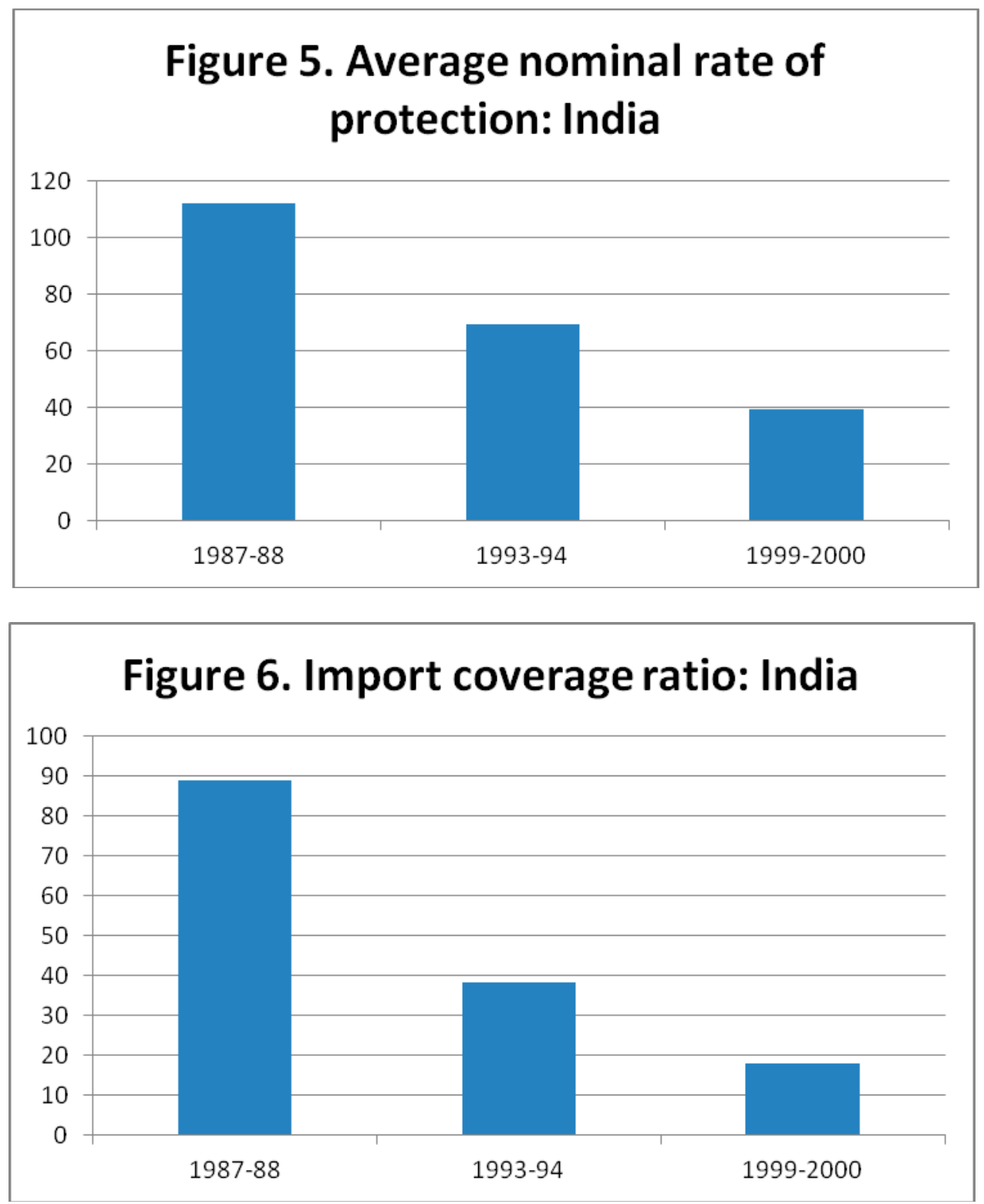


\section{Appendix}

The international trade data on India that we use in this paper is from Das (2003). This database covers 72 three-digit manufacturing industries, classified according to the National Industrial Classification 1987 (NIC-1987). The dataset includes different indicators of protection: nominal tariff rates, effective rates of protection and import coverage ratio. Together they account for both tariff and non tariff based measures of trade policy. The effective rate of protection is based on the Corden formula and is the percentage excess of domestic value-added, vis-à-vis world value-added, introduced because of tariff and other trade barriers.

$\mathrm{ERP}_{\mathrm{j}}=\left(\mathrm{VA}_{\mathrm{j}}{ }^{*}-\mathrm{VA}_{\mathrm{j}}\right) / \mathrm{VA}_{\mathrm{j}}$

Where $\mathrm{VA}_{\mathrm{j}}{ }^{*}=$ value-added of the final product $\mathrm{j}$ at free trade prices and $\mathrm{VA}_{\mathrm{j}}=$ value added of the final product $\mathrm{j}$ at tariff distorted prices.

This measures the distortion introduced due to tariff on the input prices as well as the final output prices, and therefore measures protection to domestic factors of production. The incentive structure of the domestic production process is described by the return to primary factors of production and the measure of protection based on value added is able to capture it.

Given the assumptions we can define $\mathrm{VA}_{\mathrm{j}}$ and $\mathrm{VA}_{\mathrm{j}}{ }^{*}$ as follows

$\mathrm{VA}_{\mathrm{j}}=\left(1-\Sigma \mathrm{a}_{\mathrm{ij}}\right)$ 
$\mathrm{VA}_{\mathrm{j}}^{*}=\left(1+\mathrm{t}_{\mathrm{j}}\right)-\Sigma\left(1+\mathrm{a}_{\mathrm{ij}}\right)$

Substituting (A2) and (A3) are substituted into (A1) and rearranging we can write:

$E R P_{j}=\left(T_{j}-\Sigma a_{i j} T_{i}\right) /\left(1-\Sigma a_{i j}\right)$,

Where $E R P_{j}$ is the effective rate of protection of the $j$ 'th activity (product), $T_{j}$ is the nominal tariff rate for $\mathrm{j}^{\prime}$ th activity, $\mathrm{T}_{\mathrm{i}}(\mathrm{i}=1,2, \ldots \mathrm{n})$ are the nominal tariff rates of the tradeable intermediate inputs used in the $\mathrm{j}^{\prime}$ th activity. $\mathrm{a}_{\mathrm{ij}}(\mathrm{i}=1,2, \ldots \mathrm{n})$ are the cost shares of inputs in total value of production of the $\mathrm{j}^{\text {th }}$ activity. The cost shares are computed after valuing output and tradeable inputs at world prices. The data on costs of production are obtained from the input-output tables. ${ }^{9} \Sigma \mathrm{a}_{\mathrm{ij}}$ is the sum of the shares of intermediate inputs( $(\mathrm{i} \ldots . \mathrm{n})$ in the final value of $\mathrm{j}$ and $\Sigma \mathrm{a}_{\mathrm{ij}}$ is the weighted average of input tariffs on all intermediate inputs with weights based on input shares. The concept of effective protection is well behaved in that domestic and international value added are both positive.

There are two ways of obtaining the free-trade input coefficients. First is to assume that a developed country [like USA, which has low levels of nominal tariffs] input

\footnotetext{
${ }^{9}$ It was not possible to use the cost data for the three-digit industries, as detailed data were not available for all the years of the study. A mapping was established between the I-O sectors and ASI sectors, so as to enable the I-O coefficients to substitute for the input costs of the industries. Das(2001) provides the detailed mapping for constructing ERP by industry.
} 
coefficients could approximate the world input-output coefficient. The second is to assume that free trade prices are equal to the protected prices deflated by appropriate tariff rates. This gives the free trade coefficients as:

$a_{i j}=P_{i j} / P_{j}=\left[P^{*}{ }_{i j} /\left(1+T_{i}\right)\right] /\left[P^{*} /\left(1+T_{j}\right)\right]$, where the * refers to the domestic prices.

Thus, $\mathrm{a}_{\mathrm{ij}}=\mathrm{a}_{\mathrm{ij}}\left[\left(1+\mathrm{T}_{\mathrm{j}}\right) /\left(1+\mathrm{T}_{\mathrm{i}}\right)\right]$.

The industry wise ERP's are calculated by mapping the different tariff codes with the three-digit ASI industries. The tariff rates for various product categories (items in the tariff working-schedule under BTN or HS codes) have been derived from the Customs Tariff Working Schedule. For each product category, the effective rate of duty was arrived at taking into account quantifiable exemptions and was restricted to basic and auxiliary duties. The ERP for a three-digit industry was based on the computed NRP valued at international prices. These ERP estimates are not adjusted for any exchange rate overvaluations, but nonetheless are representative of the levels and heights of effective protection found in developing countries. 